\title{
Sweet Corn Ontogeny in Response to Irrigation and Nitrogen Fertilization
}

\author{
Nahid Jafarikouhini ${ }^{1}$, Seyed Abdolreza Kazemeini ${ }^{1}$, Thomas R. Sinclair ${ }^{2 *}$ \\ ${ }^{1}$ Agricultural Engineering- Crop Production, Shiraz University, Shiraz, Iran \\ ${ }^{2}$ Department of Crop Science, North Carolina State University, Raleigh, NC 27695-7620, USA \\ *trsincla@ncsu.edu
}

Keywords: phenology, milking, silking, temperature

\begin{abstract}
To achieve optimum quality, sweet corn should be harvested at the milking stage, therefore understanding of plant phenology could be the most important aspects for economic return in this crop. Phenological sensitivity to the environment could be especially important in the management of water and nitrogen. In the current research, sweet corn ontogeny in two years was monitored in response to irrigation and nitrogen fertility: three water regimes and five nitrogen levels. The results showed that nitrogen and water application significantly affected duration in sweet corn between emergence and silking. As nitrogen and water level was increased, the days and cumulative temperature units $\left(\mathrm{TU},{ }^{\circ} \mathrm{C}\right)$ from sowing to silking significantly increased. In 2014, sowing to silking ranged from 66 days equal to $1035 \mathrm{TU}$ with deficit water and nitrogen treatment to 72 days equal to $1140 \mathrm{TU}$ at full irrigation and highest nitrogen treatment. In 2015, the range of sowing to silking was from 67 days equal to 1090 TU, to 73 days equal to 1180 TU. In contrast, neither nitrogen nor water treatments had a large influence on the duration of the silking to milking period. Across the two years the duration of silking to milking was approximately 506 TU. Therefore, once silking date had been resolved harvest date of sweet corn could be readily predicted independent of water or nitrogen treatment as occurring about $506 \mathrm{TU}$ following silking.
\end{abstract}

\section{Introduction}

Sweet corn (Zea mays L. saccharata) is one of the most popular vegetables for human consumption in countries like USA and Canada, and is becoming popular in India and Asian countries. The name sweet corn, as opposed to field maize, is used to designate a series of genotypes with natural recessive mutations that cause the differential accumulation of sugar in the endosperm. Sweet corn kernels have a sugar content of more than $25 \%$ during the milking stage [1]. Sweet corn harvested at the milking stage is prepared and eaten as a vegetable, rather than a grain unlike other maize varieties which are harvested at seed physiological maturity [2].

Sweet corn fetches higher prices as compared to field maize, but its yields are much lower. The basis for the low yields of sweet corn is not resolved but could relate to the impact of water and nitrogen on its development and growth [3]. One report indicated that high nitrogen fertilization of two landrace of sweet corn cultivar SWB resulted in delayed tasseling and maturity [3].

Phenology is one of the most important aspects of yield determination and variation in sweet corn since the crop needs to be harvested precisely at the milking stage for optimum quality. It is therefore, essential to predict phenological responses under varying environmental conditions, including amounts of nitrogen and water treatment [4], to accurately target harvest date. For example, it was previously observed that the duration of the days to tasseling, silking, and maturity in field maize increased linearly with increasing $\mathrm{N}$ fertilization [5]. Lengthening of the time between anthesis to silking could lead to increased growth and yield, through a lengthened period of active photosynthesis. It has been observed in field maize that $\mathrm{N}$ restriction from sowing to eight emerged leaves (V8 stage) causes 30\% reduction in yield, withholding $\mathrm{N}$ supply from V8 to maturity reduces yield by $22 \%$; however, there was no yield reduction when $\mathrm{N}$ was restricted around silking to physiological maturity [6]. Thus, $\mathrm{N}$ is considered as one of the most important factors affecting field maize phenology [4]. 
Generally, water-deficit stress reduces $\mathrm{N}$ availability and hasten leaf senescence, decreasing the leaf expansion and final leaf area, and duration of grain filling [7]. In maize, depending on the timing of the drought the impact on dry matter accumulation can result from decreased leaf area or radiation use efficiency [8].

Given the reports of phenology cited above were for field maize and the existence of only the single report for sweet corn [3], and that harvest date is sweet corn is critical in deterring quality for consumption, the objective of this study was to document sweet corn phenology in response to variable nitrogen and water inputs. The practical implication of this study was the development of guidelines in predicting sweet corn harvest date as influenced by nitrogen and water availability. Observations were made during two years of field study with applications of three levels of irrigation and five levels of nitrogen fertilization.

\section{Materials and Methods}

This field study was done on a silty clay loam soil (fine, mixed, mesic, Cacixerollic Xerochrepts) at Shiraz University (52 $02^{\prime} \mathrm{E}, 2^{\circ} 56^{\prime} \mathrm{N}, 1850 \mathrm{~m}$ above sea level), Shiraz, Iran. The study was done in two years on experimental sites that had no prior manure history and were under continuous maize production. A soil test before sowing was done for identifying the soil properties (Table 1).

Uniform sweet corn seeds (hybrid Merit EX 08745857 R) were sown on June 18, 2014 and July 10, 2015. A pneumatic precision planter (John Deere 7000 MaxEmerge) was used with a row spacing of $75 \mathrm{~cm}$. At the $\mathrm{V}_{3}$ stage, seedlings were thinned to a density of 8 plants $\mathrm{m}^{-2}$. There were no serious problem with insects, and diseases and so there was no need for chemical control. Plots were also kept chemically free of weeds using 2,4-D (Opti Amine, $1.5 \mathrm{~g} \mathrm{~L}^{-1}$ at 5-6 leaf stage) and Ultima (Finalsan Plus, $175 \mathrm{~g} \mathrm{~L}^{-1}$ at the 6-7 leaf stage).

Three water regimes were initiated using a drip irrigation system after seedling establishment based on estimates of fraction of extractable soil water. The amounts of irrigation were estimated based on soil moisture measurements between rows using time-domain reflectometry rods (top $0.2 \mathrm{~m}$ of soil) and a neutron-probe reading at $1 \mathrm{~m}$ depth. Measurements were made in each plot. Irrigation was applied when the water in the soil profile of the wettest plot decreased to about $30 \%$ of total extractable soil water [9]. The fully watered plot received sufficient water calculated to return to the soil $100 \%$ of field capacity (I100). In addition, two water-deficit treatments were established by applying $80 \%$ (I80) or $60 \%$ (I60) of the water applied to the I100 treatment.

Five nitrogen $(\mathrm{N})$ treatments were also included in the experiment: $0\left(\mathrm{~N}_{0}\right), 75\left(\mathrm{~N}_{75}\right), 125\left(\mathrm{~N}_{125}\right)$, $175\left(\mathrm{~N}_{175}\right)$ and $225\left(\mathrm{~N}_{225}\right) \mathrm{kg} \mathrm{N} \mathrm{ha}^{-1}$. Nitrogen fertilization was achieved by hand broadcast of urea $(46 \% \mathrm{~N})$. All treatments were applied in three applications: 50\% two weeks after sowing, 25\% just before five-leaf stage, and $25 \%$ just before the silking stage. All plots were also fertilized at sowing with $150 \mathrm{~kg} \mathrm{P} \mathrm{ha}^{-1}$ as triple superphosphate $(45 \%)$ and $100 \mathrm{~kg} \mathrm{~K} \mathrm{ha}^{-1}$ as $60 \%$ potassium sulphate.

The 15 treatments (3 irrigation x $5 \mathrm{~N}$ fertilizer, as described above) were in a split-plot experiment based on randomized block design with three replicates. In both years, the three irrigation regimes were the main plots and the five $\mathrm{N}$ fertilizer treatments were the sub-plots $(4 \mathrm{~m} \times$ $3 \mathrm{~m})$.

Each sub-pot was observed every 2-3 days to determine the dates when the plants achieved the silking and milking stages. Silking was defined to have occurred when silk was visible outside the husk in $50 \%$ of plants. Milking was defined as the date when $50 \%$ of the plants showed milking stage, i.e. when the kernels are beginning to yellow outside and contain a milky white inner fluid, equal to $80 \%$ moisture level.

From these observations, the number of days from sowing to silking and days from silking to milking were calculated. Daily weather data including minimum temperature, maximum temperature, average temperature, reference evapotranspiration $\left(\mathrm{ET}_{0}\right)$ and maximum vapor pressure deficit (VPD), were obtained from the weather station of Badjgah at College of Agriculture, at a distance of $200 \mathrm{~m}$ from the experimental fields. In addition, the cumulative temperature units (TU) to reach each of the phenological stages were calculated. The daily TU were calculated from air temperatures with a base temperature of $10^{\circ} \mathrm{C}$ and an optimum temperature of $34^{\circ} \mathrm{C}$ [10]. 
After variance uniformity test, data was subjected to analysis of variance (ANOVA) for determining significantly the main effects and interactions. Then the means were compared using least significant difference (LSD) at $1 \%$ probability level. The statistical analyses were done using SAS software ver. 11.4.

\section{Results}

Minimum, maximum and average daily temperature had considerable variation through much of the growing season. The lowest average temperature in 2014 was $24.1{ }^{\circ} \mathrm{C}$ occurring 100 days after sowing (DAS) and the highest value was $33.6^{\circ} \mathrm{C}$ occurring on 40 DAS. In 2015 , the lowest and highest average temperatures occurred on 95 DAS $\left(24.1^{\circ} \mathrm{C}\right)$ and 26 DAS $\left(33.1^{\circ} \mathrm{C}\right)$, respectively. Daily temperature units in each season are shown in Figure 1.

To document the water-demand in each season, daily maximum vapor pressure deficit (VPD) were examined. Daily maximum VPD ranged from $2.32 \mathrm{kPa}$ to $4.43 \mathrm{kPa}$ in 2014 and $2.01 \mathrm{kPa}$ to $4.33 \mathrm{kPa}$ in 2015 (Figure 1). The maximum VPD occurred early in the growing season (27 and 26 days after sowing in the two years) and minimum VPD occurred late in the growing season (100 and 95 days after sowing in the two years). Reference daily evapotranspiration varied during growing seasons ranging 5.0 to $7.0 \mathrm{~mm}$ in 2014 and 4.3 to $6.9 \mathrm{~mm}$ in 2015 (Figure 1).

Days from sowing to silking significantly differed among water and nitrogen treatments (Figure 2). On average across $N$ treatments, water deficit reduced duration of sowing to silking development as compared to the $\mathrm{I}_{100}$ treatment. Under the $\mathrm{I}_{100}$ treatment, the duration of sowing to silking was 71.4 days in 2014 and 72.2 days in 2015. The average durations under the I $_{80}$ regime were decreased to 69.6 and 70.2 days in 2014 and 2015, respectively. Under the $I_{60}$ regime, average duration decreased further to 67.4 and 68 days in 2014 and 2015, respectively.

The impact of the $\mathrm{N}$ treatment of the duration of sowing to silking was less than the irrigation treatment. In 2014, there was no significant difference among days from sowing to silking in $\mathrm{N}$ levels under $\mathrm{I}_{100}$ and $\mathrm{I}_{80}$ regimes. In 2015, there was no difference among the $\mathrm{N}$ treatments in $\mathrm{I}_{100}$ in days from sowing to silking. In $\mathrm{I}_{80}$ in the first year and in the $\mathrm{I}_{80}$ and $\mathrm{I}_{60}$ regimes in both years, days from sowing to silking was decreased as the $\mathrm{N}$ levels decreased. That is, the shortest duration from sowing to silking was observed in $\mathrm{I}_{60}$ without $\mathrm{N}$ (Figure 2).

Similar to days from sowing to silking, TU from sowing to silking was significantly affected by nitrogen and water treatments (Figure 3). In 2014, as irrigation regimes were decreased from $\mathrm{I}_{100}$ to $\mathrm{I}_{80}$ or $\mathrm{I}_{60}$, the average $\mathrm{TU}$ from sowing to silking was shortened by 29.0 and $76.8{ }^{\circ} \mathrm{C}$, respectively. In 2015 , average $\mathrm{TU}$ from sowing to silking was decreased as compared to the $\mathrm{I}_{100}$ treatment by 30 and $61{ }^{\circ} \mathrm{C}$, in $\mathrm{I}_{60}$ and $\mathrm{I}_{80}$ treatments, respectively. Temperature unit from sowing to silking differed between $\mathrm{N}$ levels within an irrigation treatment only in $\mathrm{I}_{60}$.

Days from silking to milking was negligibly affected by nitrogen and water treatments (Figure 4). The lack of difference is illustrated among irrigation treatments in which silking to milking was $32.2,31.6$ and 31.0 days in 2014 under $\mathrm{I}_{100}, \mathrm{I}_{80}$ and $\mathrm{I}_{60}$ regimes, respectably. In 2015, these value were 34.0, 33.4 and 33.2 days, respectively. In 2014, only in $\mathrm{I}_{60}$ did $\mathrm{N}$ level had significant effect on silking to milking, so that the lowest days from silking to milking was observed in $75 \mathrm{~kg} \mathrm{~N} \mathrm{ha}^{-1}$. Without $\mathrm{N}$ application in this year, days from silking to milking was non-significantly lower that $\mathrm{N}$ applied treatments (Figure 4).

In contrast to nitrogen, water deficit $\left(\mathrm{I}_{60}\right)$ had significantly negative effect only in 125 and $75 \mathrm{~kg}$ $\mathrm{N} \mathrm{ha}^{-1}$ treatments resulting in fewer days from silking to milking in the most severe water-deficit stress. In 2015, there was no clear cut response among the $\mathrm{N}$ treatments (Figure 4).

No clear cut response was also reflected in TU from silking to milking among water-deficit treatments (Figure 5). Average of TU for silking-milking was essentially equal among irrigation treatments in each year with values of 486, 489 and 490 TU in 2014 and 529, 524 and 523 TU in 2015 in $\mathrm{I}_{100}, \mathrm{I}_{80}$ and $\mathrm{I}_{60}$, respectively. The TU average silking to milking in 2014 was nearly constant across nitrogen treatments ranging from only 486 to 492 TU. On average, irrigation regimes had no significant effect on TU (Figure 5). 


\section{Discussion}

Accurate prediction of phenology is critical in sweet corn to guide harvesting of the crop at the prime stage of milking. Weather conditions, particularly temperature, have been identified as key in influencing the duration of phenology stages in field maize [5]. In sweet corn, Khan et al. [3] suggested that the reason for late tasseling in their research on sweet corn could be low air temperature at sowing causing delay in emergence and slow seedling growth. In a cool soil, seeds take more days to emergence. Sacks et al. (2010) stated that late sowing resulted in reduced cumulative TU for a uniform emergence and optimum seedling growth, which may have a shortened growth cycle in terms of number of days for the crop. Increase in nitrogen rate increases the photosynthesis rate, which results in the leaf longevity and delayed phenological development in maize [5].

The results of the experiments presented in this paper showed that increasing amounts of nitrogen application extended the duration of sowing to silking in sweet corn. Similar to our finding, in a research on field maize it was also shown that days from sowing to silking were lengthened with increased $\mathrm{N}$ application rate [5]. Our finding revealed that there was a clear cut trend in response of TU to nitrogen and water, as irrigation amount was reduced (i.e. $\mathrm{I}_{100}$ to $\mathrm{I}_{60}$ ) or nitrogen levels was decreased causing a decrease in TU for the development of sweet corn from sowing to silking. In field maize, a linear relationship was found between $\mathrm{N}$ rates and days to tasseling, silking, and maturity [5]. Amanullah and Khalil [4] reported that nitrogen stress of field maize delays the appearance of leaves, and attributed distribution of rainfall as the main reason behind the delay in phenological parameters. Delay in the phenological characteristics (days to tasseling, to silking and to physiological maturity) through high $\mathrm{N}$ applications and split applications resulted in the highest field maize yield [4]. It has been reported that high nitrogen rate resulted in extended days to silking and milking in both sweet corn [3] and field maize $[5,6]$.

It was observed in this study of sweet corn that neither nitrogen nor water had a consistent influence on days between silking to milking. Within each of the two years of study the duration of silking to milking was essentially constant. In 2014 the average duration was 488 TU and in 2015 it was $524 \mathrm{TU}$. There was no apparent basis for the difference in the average silking-to-milking TU between the two years. Nevertheless, an average TU for the two years 506 TU offers a reasonable practical estimate for predicting the occurrence of milking following silking independent of nitrogen and water treatments.

Based on the findings in this study, water and nitrogen influence development in sweet corn phenology until silking and after that they don't have considerable impact. Therefore, duration to silking is identified as the stage where water and nitrogen affect sweet maize phenology. However, once silking date is established, milking stage (and hence harvesting date) can be predicted by producers and researchers based on approximately $506 \mathrm{TU}$ following the silking stage regardless of the nitrogen and water conditions.

\section{Acknowledgment}

Authors are grateful of the staff and student of Department of Crop Production and Plant Breeding and Department of Irrigation Sciences, College of Agriculture, Shiraz University for their kind assistant. This project was funded by a grant from research council of Shiraz University, Shiraz, Iran.

Table 1. The results of soil analysis before sowing at the experimental site in two years at $0-30 \mathrm{~cm}$ depth

\begin{tabular}{ccccccccc}
\hline Year & $\begin{array}{c}\text { Bulk } \\
\text { density } \\
\left(\mathrm{g} \mathrm{cm}^{-3}\right)\end{array}$ & $\begin{array}{c}\text { Organic } \\
\text { matter } \\
(\%)\end{array}$ & $\begin{array}{c}\text { Field } \\
\text { capacity } \\
\left(\mathrm{cm}^{3} \mathrm{~cm}^{-3}\right)\end{array}$ & Texture & $\mathrm{pH}$ & $\begin{array}{c}\text { Available } \\
\mathrm{N}(\%)\end{array}$ & $\begin{array}{c}\text { Available } \\
\mathrm{P} \\
\left(\mathrm{mg} \mathrm{kg}^{-1}\right)\end{array}$ & $\begin{array}{c}\mathrm{K} \\
\mathrm{mg} \mathrm{kg}^{-1}\end{array}$ \\
\hline 2014 & 1.4 & 0.6 & 0.33 & Silty clay & 7.50 & 0.23 & 21 & 329 \\
2015 & 1.5 & 0.7 & 0.32 & loam & 7.45 & 0.25 & 16 & 315 \\
\hline
\end{tabular}



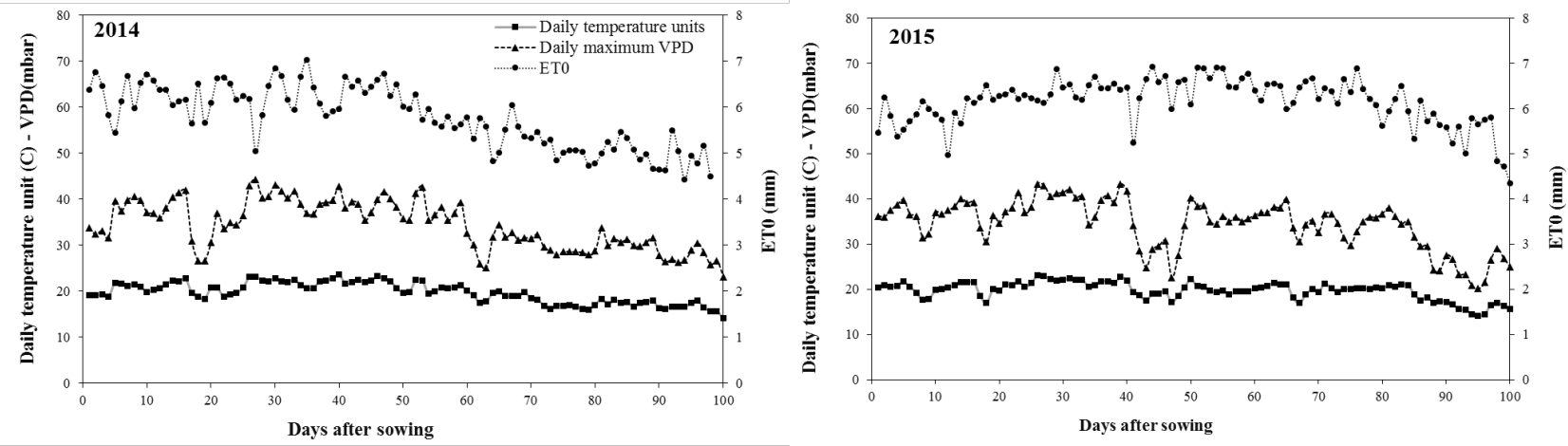

Figure 1. Weather data and reference evapotranspiration in 2014 and 2015 in the experimental site
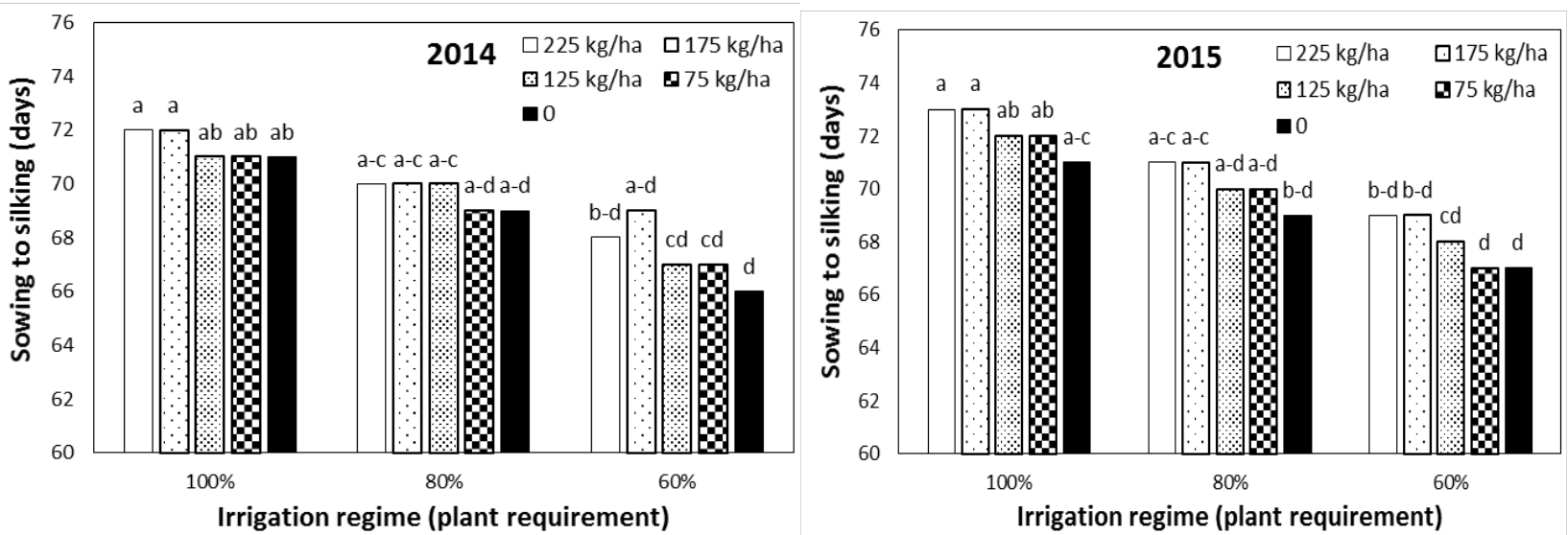

Figure 2. Days from sowing to silking of sweet corn in response to irrigation and nitrogen. The column with at least a similar letter had no significantly difference based on LSD at $1 \%$ probability level
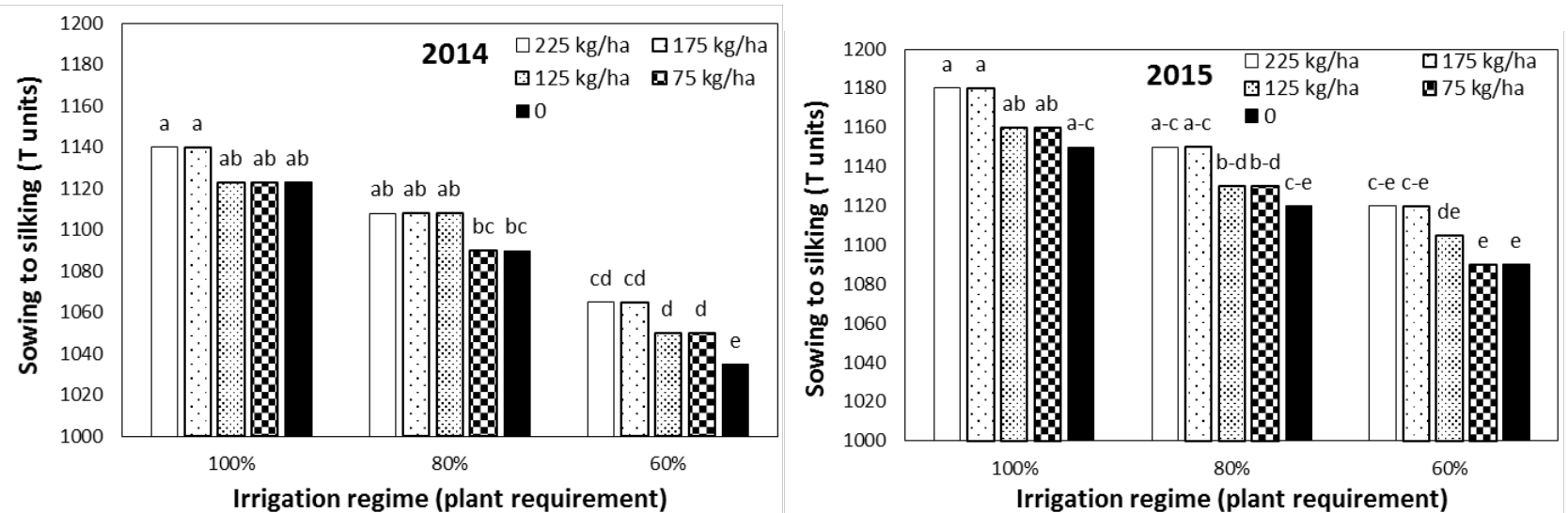

Figure 3. Time from sowing to silking of sweet corn in response to irrigation and nitrogen based on temperature units. The column with at least a similar letter had no significantly difference based on LSD at $1 \%$ probability level 

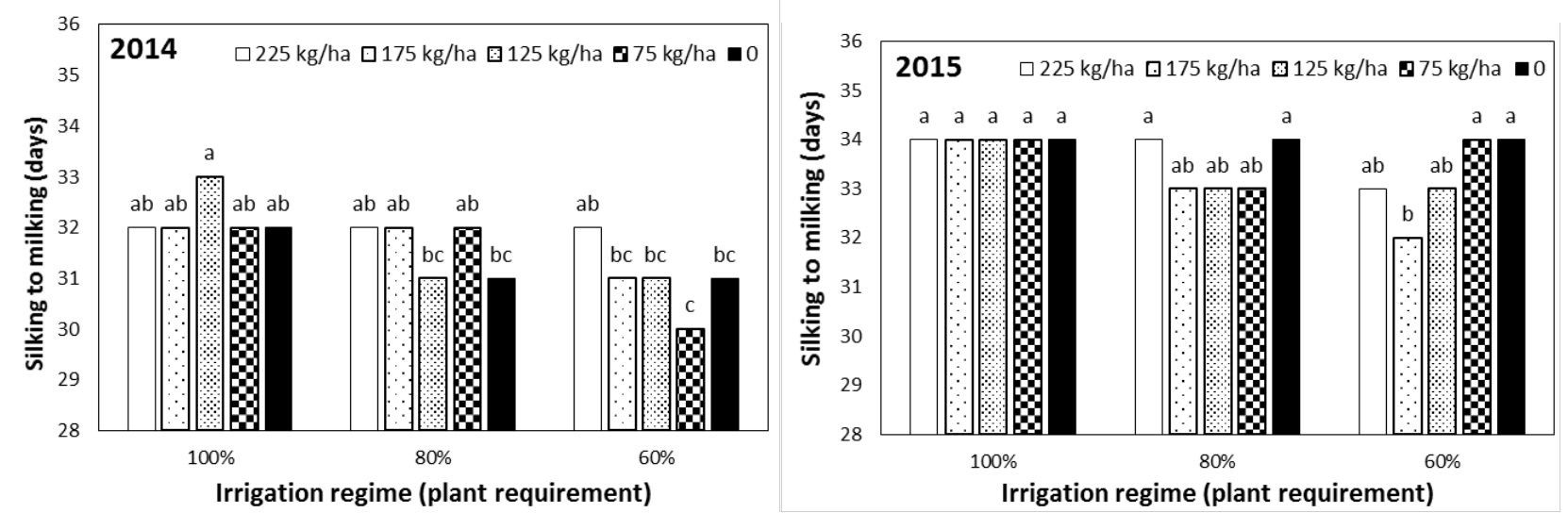

Figure 4. Days from silking to milking of sweet corn in response to irrigation and nitrogen. The column with at least a similar letter had no significantly difference based on LSD at $1 \%$ probability level
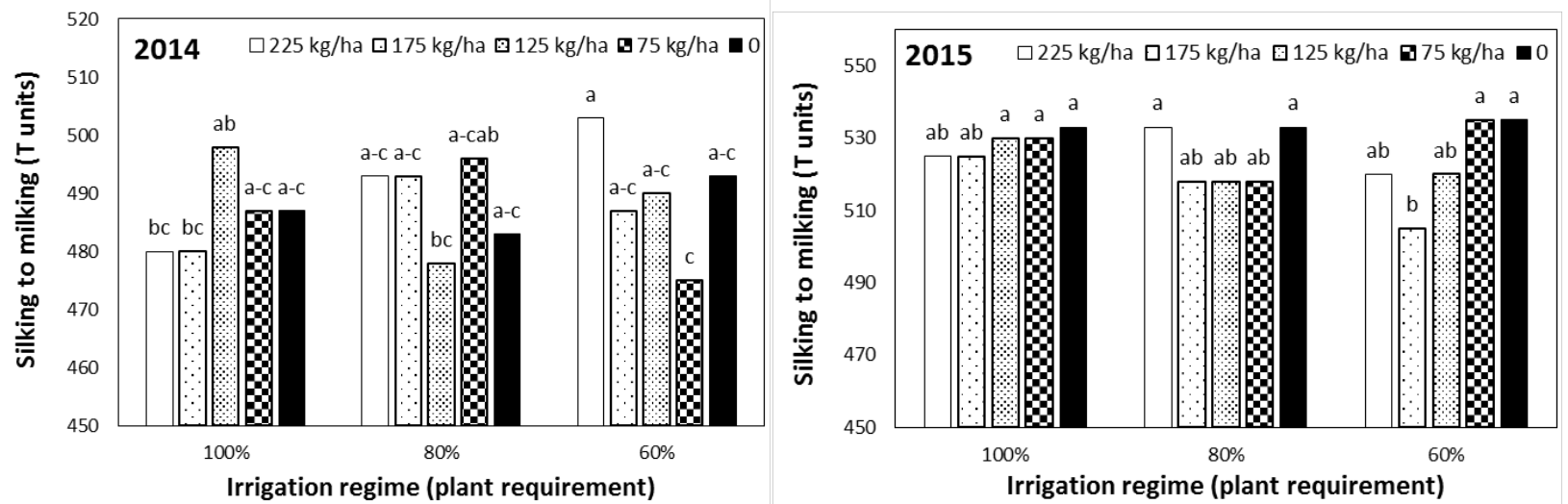

Figure 5. Time from silking to milking of sweet corn in response to irrigation and nitrogen based on temperature units. The column with at least a similar letter had no significantly difference based on LSD at $1 \%$ probability level

\section{References}

[1] I. Singh, , S. Langyan, P. Yadava. Sweet corn and corn-based sweeteners. Sugar tech, 16(2) (2014) 144-149.

[2] C.E. Scott and A.L. Eldridge. Comparison of carotenoid content in fresh, frozen and canned corn. Journal of Food Composition and Analysis 18 (2005) 551-559.

[3] Z.H. Khan, S.K. Khalil, A. Iqbal, I. Ullah, M. Ali, T. Shah, W. Wu, F. Shah. Nitrogen doses and plant density affect phenology and yield of sweet corn. Fresenius Environmental Bulletin, 26(6) (2017) 3809-3815.

[4] R.A.K. Amanullah, S.K. Khalil. Plant density and nitrogen effects on maize phenology and grain yield. Journal of plant nutrition, 32(2) (2009) 246-260.

[5] D.T. Gungula, J.G. Kling, A.O. Togun. CERES-Maize predictions of maize phenology under nitrogen-stressed conditions in Nigeria. Agronomy Journal 95 (2003) 892-899.

[6] K.D. Subedi, B.L. Ma. Nitrogen uptake and partitioning in stay green and leafy maize hybrids. Crop Science 45 (2005) 740-747.

[7] R.E. Brevedan, D.B. Egli. Short periods of water stress during seed filling, leaf senescence, and yield of soybean. Crop Science, 43(6) (2003) 2083-2088. 
[8] R.C. Muchow. Comparative productivity of maize, sorghum and pearl millet in a semi-arid tropical environment II. Effect of water deficits. Field Crop Research 20 (1989) 207-219.

[9] S.W. Ritchie, J.J. Hanway, G.O. Benson. How a maize plant develops. Special Report No. 48. Ames: Iowa State University of Science and Technology Cooperative Extension Services, Iowa (1993).

[10] Z.F. Arslan, M.M. Williams, R. Becker, V.A. Fritz, R.E. Peachey, T.L. Rabaey. Alternatives to atrazine for weed management in processing sweet corn. Weed Science, 64(3) (2016) 531539. 